\title{
Analysis Of Environmental Impact With The Life Cycle Assessment (LCA) Method On Tofu Production
}

\author{
Masayu Rosyidah ${ }^{1 *}$, Ansyori Masruri ${ }^{2}$, Romyzar Arya Putra ${ }^{3}$, Mayanita $^{4}$, Ananda $^{5}$, Cindy $^{6}$ \\ ${ }^{1,2}$ Teacher Industrial Engineering Study Program, Engineering Faculty \\ 3,4,5,6 Student Industrial Engineering Study Program, Engineering Faculty \\ Universitas Muhammadiyah Palembang, Palembang, South Sumatra 30263, Indonesia. \\ ${ }^{*}$ Corresponding author: \\ Email: rosyidahmasayu@gmail.com
}

\begin{abstract}
Tofu is a typical Indonesian food. The tofu production process has its own impact on the environment because the rest of the production results in solid and liquid waste. If the processing or utilization of the waste products is not carried out, it will pollute the surrounding environment. The aim of this research is to identify the environmental impact of the tofu production process. The method used in this research is the method of mixed method simapro program assisted 7. From the results showed that the production process knows it can cause environmental pollution, it is seen from the damage category. Score a single score of 4076,345 Pt, with an environmental impact of Human Health of 1701.54 (41.7\%), Ecosystem Quality of 1409.057 (34.6\%), and Resources of 965.7484 (23.7\%). Based on research results of several categories of the study, obtained on alternative improvements to reduce environmental impact by replacing firewood with biogas as fuel.
\end{abstract}

Keywords : Biogas, Life Cycle Assessment, Environmental Pollution, Production Know, SimaPro

\section{INTRODUCTION}

The role of small industries in several areas of Semarang Regency is very important in supporting the economy, especially around these industrial locations. One small industry that has the potential to develop is the tofu industry [1]. Tofu is a typical Indonesian food. The production of tofu is occupied by most of the Indonesian people, because it can be produced without the need for large and complicated tools.

On the other hand, the tofu production process has its own impact on the environment, because it is the residue of the production (waste). Waste is the remainder of a business and / or activity[2]. Solid waste from the tofu industry in Indonesia is known as tofu dregs. Tofu dregs are the residual juice of soybean pulp and still have a relatively high nutritional content [3]. Tofu liquid waste contains high levels of organic compounds and will pollute the environment and endanger human health if discharged into rivers without undergoing a waste treatment process [4].

From the explanation above, if the waste produced from the tofu production process is not processed or reused, it will pollute the surrounding environment, living things, plants, animals, soil and air. Continuous production process which does not see its effect on the surrounding environment, it will be an imbalance of nature and ecosystems. Pollution on land, air, sea or river, or other natural disasters [5]. The advantage of LCA is that it is comprehensive because it is able to analyze the potential environmental impacts on processes involved in the life cycle of a product [6]. With LCA, it can be seen that the resources used (input) of a process and the materials produced (output) of a process [6].

Life Cycle Assessment (LCA) is a tool or method for identifying environmental impacts with several stages of analysis. Life cycle assessment (LCA) is a method or tool used to analyze the environmental impacts that occur as a result of the manufacturing process of a product. The advantage of LCA is that it is comprehensive because it is able to analyze the potential environmental impacts on processes involved in the life cycle of a product. With LCA, it can be seen that the resources used (input) of a process and the 
materials produced (output) of a process [7]. The focus of LCA is usually on contributions to regional and global scale impacts, including resource consumption [8]. Life Cycle Analysis (LCA) or often called Life Cycle Assessment is a cradle to grave based method (analysis of the entire cycle from the production process to waste treatment) which is used to determine the amount of energy, costs, and environmental impacts caused by the product life cycle stages. starting from the time of taking raw materials until the product is finished being used by consumers. Every step of the LCA is described in international standards (ISO 14040, ISO 14041). This step is always repeated, with the level of detail and effort depending on the research objectives (World Business Council for Sustainable Development, 2002). These steps are: (1) defining objectives and scope, (2) inventory analysis, (3) impact analysis / assessment, (4) interpretation (ISO 14040, 2006) [9].

The purpose of this study is m enganalisa the environmental impact of the production process knows, mengidentifikasi factors that influence the environmental impact, and m emberikan recommendations for improvement to reduce the negative environmental impact.

\section{METHODS}

The research took place from March to July 2020. The research was conducted in one of the tofu production process in the Veteran Jaya Village, Martapura District, East OKU. Data collected from primary data derived from interviews and observations. The research approach used both quantitative and qualitative methods (mixed method). Mixed Methods Research (MMR) is a research method that is applied when the researcher has questions that need to be tested in terms of outcomes and processes, and involves a combination of quantitative and qualitative methods in one study. Because it focuses on outcomes and processes, MMR design is commonly used in program evaluation research [10]. The stages of the LCA method used are the LCA procedure according to ISO 14040 which consists of four stages, namely goal and scope definition, life cycle inventory, life cycle impact assessmen, and interpretation, assisted by the Simapro program.

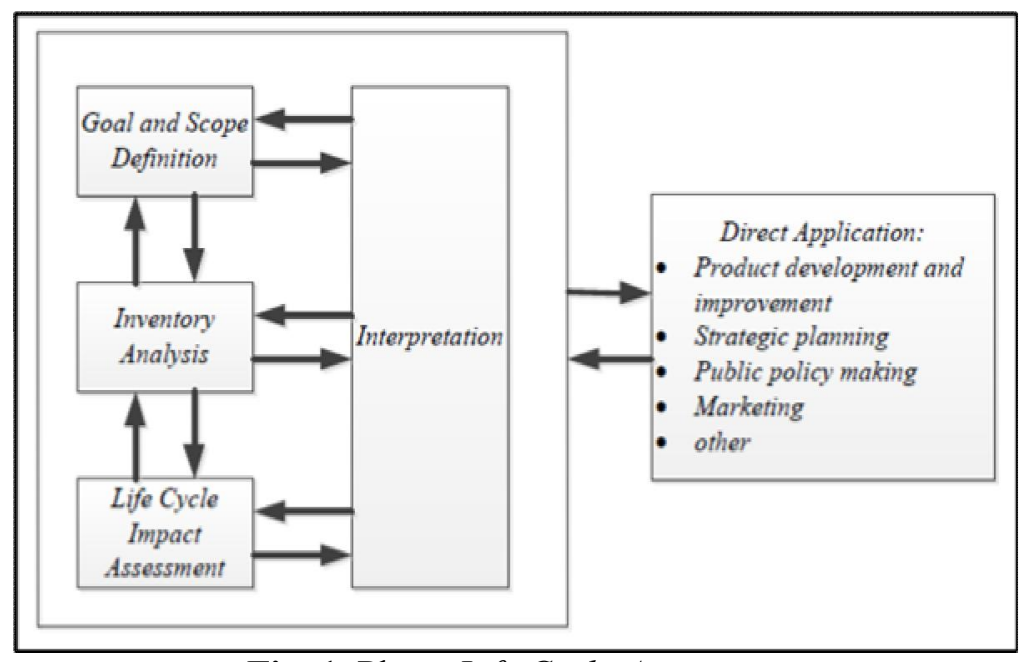

Fig. 1. Phase Life Cycle Assesment

\section{RESULT}

\section{Tofu Production Process}

Fig 2 communicating groove production processes that occur in the industry know. The tofu production process begins with soaking and washing the soybeans for 2-3 hours, followed by milling using a diesel-powered mill, so that it will produce pulp. The next process of cooking aims to improve taste and aroma, kill bacteria, and facilitate protein coagulation. After becoming slurry, it is filtered. Filtering aims to separate the soybean juice from the pulp, to produce an extract. The result of the extract was added with vinegar so that it would clot, and the tofu was ready to be printed. 


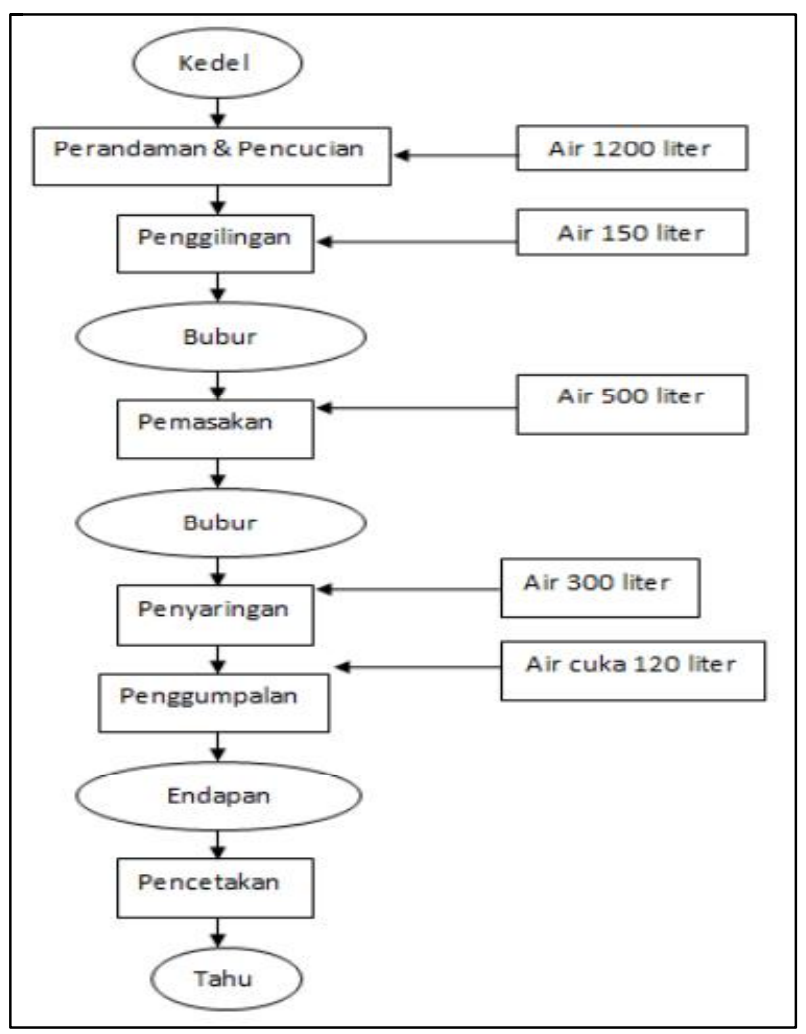

Fig. 2. Tofu Production Process Flow

\section{LIFE CYCLE ASSESSMENT DATA PROCESSING}

In processing the Life Cycle Assessment data, this stage is assisted by using the SimaPro 7 Software. The following is a table of Input Output in the production process.

Table 1 . Input Output

\begin{tabular}{|c|c|c|}
\hline \multirow{2}{*}{ Data Material Proses Produksi } & Input & Output \\
\cline { 2 - 3 } & Kedelai & $4,200 \mathrm{Kg}$ \\
\cline { 2 - 3 } & Air & $64,500 \mathrm{Liter}$ \\
\cline { 2 - 3 } & Asam Cuka & $3,600 \mathrm{Liter}$ \\
\hline Konsumsi Energi Solar & Energi Solar & $2,150.1 \mathrm{MJ}$ \\
\hline Konsumsi Energi Kayu Bakar & Energi Kayu Bakar & $441,000 \mathrm{MJ}$ \\
\hline Energi Listrik & Natural Gas (listrik) & $18.019 \mathrm{kWh}$ \\
\hline
\end{tabular}

\section{RESULTS OF DATA PROCESSING}

Several stages are carried out in the impact assessment, among others, namely characterization, normalization, and Single Score. From the results of table 2 above, then characterization is carried out, and results in the value in table 2 .

Table 2 . Table of Characterization Value

\begin{tabular}{|c|l|l|c|c|c|}
\hline Impact Cateegory & Total & Material & EnergiListrik & EnergiBiomassa & EnergiSolar \\
\hline Carcinogens & $100 \%$ & 22.10144 & 0.0000012324166 & 77.85999 & 0.038575 \\
\hline Resp. organics & $100 \%$ & 48.23993 & 0.004501 & 50.9011 & 0.854473 \\
\hline Resp. inorganics & $100 \%$ & 7.544798 & 0.012637 & 91.5312 & 0.911366 \\
\hline Climate change & $100 \%$ & 41.18592 & 0.158435 & 56.394 & 2.261646 \\
\hline Radiation & $100 \%$ & 35.65536 & 0 & 64.28713 & 0.05751 \\
\hline Ozone layer & $100 \%$ & 71.7393 & 0 & 26.66805 & 1.592651 \\
\hline Ecotoxicity & $100 \%$ & 21.50833 & 0.0000012138127 & 78.44397 & 0.047707 \\
\hline Acidification/ Eutrophication & $100 \%$ & 10.17899 & 0.024015 & 88.19351 & 1.603485 \\
\hline
\end{tabular}




\begin{tabular}{|c|c|c|c|c|c|}
\hline Land use & $100 \%$ & 65.28123 & 0 & 34.71093 & 0.007836 \\
\hline Minerals & $100 \%$ & 44.4057 & 0 & 55.50908 & 0.085201 \\
\hline
\end{tabular}

Table 2 above explains the percentage results of material and energy use against 10 categories of environmental damage impacts. The use of biomass energy has the highest impact on damage in 8 impact categories including carcinogens, respiratory organic, respiratory inorganic, climate change, radiation, ecotoxicity, acidification / eutrophication, Minerals, while the use of manufactured materials has an impact on environmental damage in the Ozone layer and Land Use categories. The consumption of electricity and solar energy has a low percentage which does not really have an impact on environmental damage around the tofu production process. The table above can also be illustrated in Figure 3.

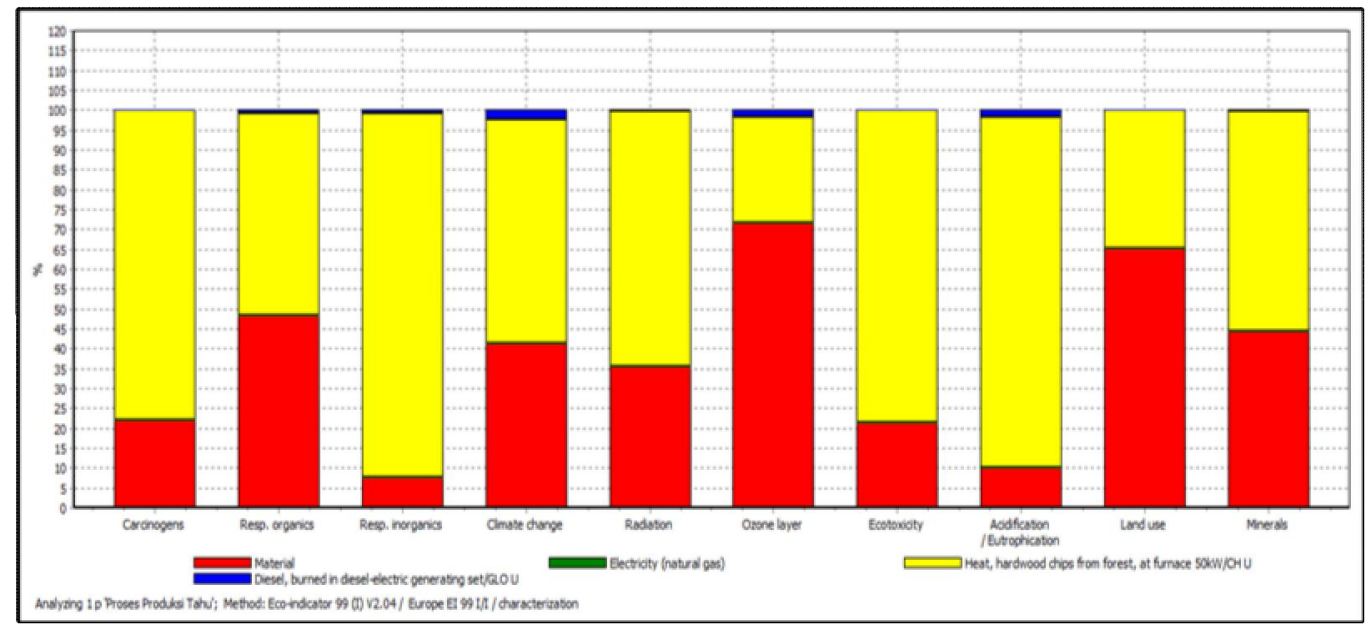

Fig. 3. Characterization diagram

Normalization value is obtained by dividing the characterization value by the reference value (normal). The result of the division is the value impact category in which the value of having a uniform unit, so that the value of impact category can be compared with one another in table 3 and drawing four.

Table 3. Table of Normalization Values

\begin{tabular}{|c|c|c|c|c|c|}
\hline Impact Cateegory & Total & Material & $\begin{array}{c}\text { Energi } \\
\text { Listrik }\end{array}$ & $\begin{array}{c}\text { Energi } \\
\text { Biomasa }\end{array}$ & $\begin{array}{c}\text { Energi } \\
\text { Solar }\end{array}$ \\
\hline Carcinogens & 0.109013 & 0.024094 & 0.000134350 & 0.084878 & 0.0000420518 \\
\hline Resp. organics & 0.004572 & 0.002206 & 0.000205794 & 0.002327 & 0.0000390662 \\
\hline Resp. inorganics & 2.776564 & 0.209486 & 0.000351 & 2.541422 & 0.025305 \\
\hline Climate change & 0.202778 & 0.083516 & 0.000321 & 0.114354 & 0.004586 \\
\hline Radiation & 0.000632 & 0.000225 & 0 & 0.000407 & 0.0000363687 \\
\hline Ozone layer & 0.000151 & 0.000108 & 0 & 0.0004019677 & 0.0000240060 \\
\hline Ecotoxicity & 0.069987 & 0.015053 & 0.000849506 & 0.0549 & 0.0000333888 \\
\hline $\begin{array}{c}\text { Acidification/ } \\
\text { Eutrophication }\end{array}$ & 0.246984 & 0.02514 & 0.000593130 & 0.217824 & 0.00396 \\
\hline Land use & 5.319256 & 3.472476 & 0 & 1.846363 & 0.000417 \\
\hline Minerals & 4.828742 & 2.144237 & 0 & 2.680391 & 0.004114 \\
\hline
\end{tabular}




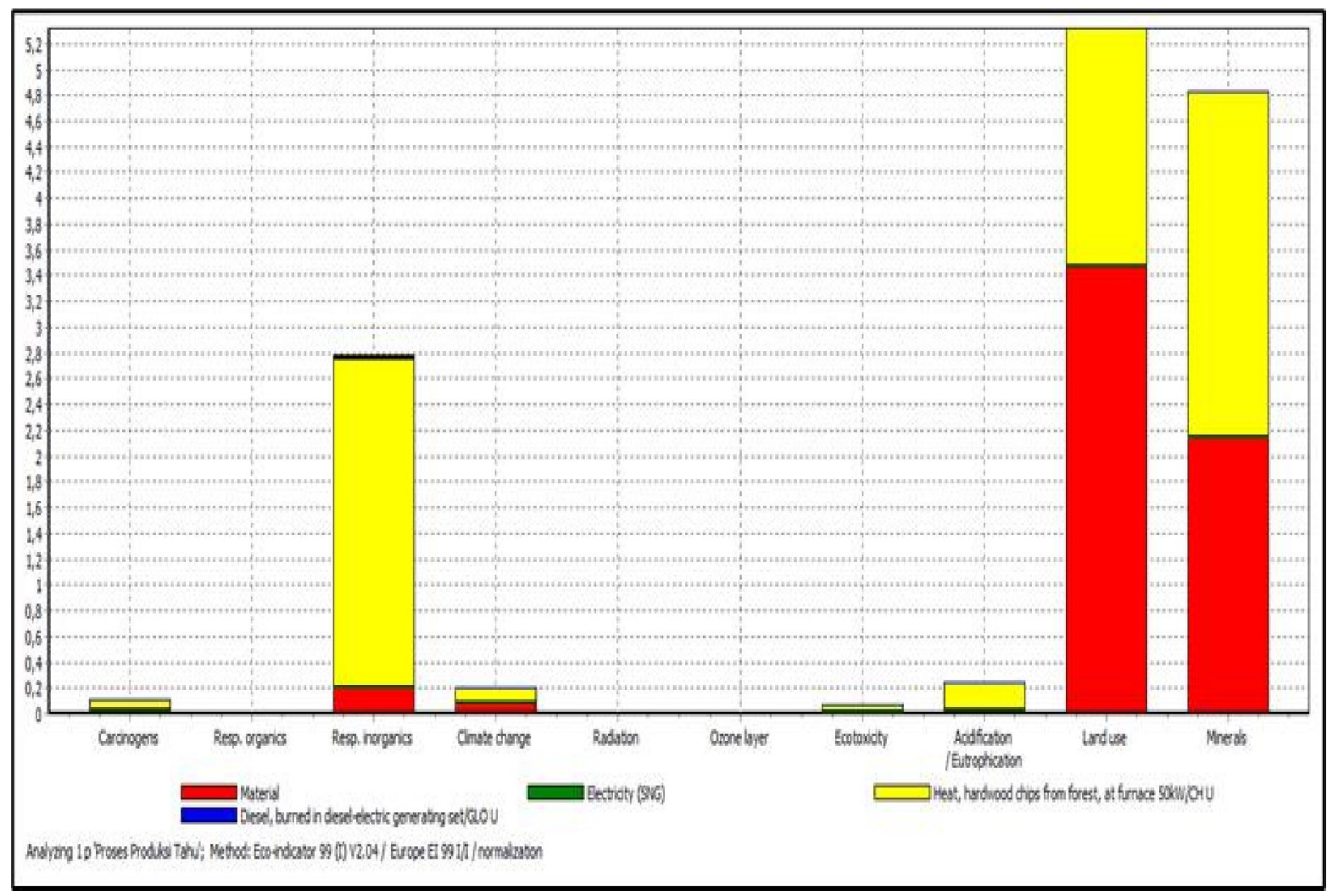

Fig. 4. Normalization Value Diagram

From table 3, data on the contribution of each process that has an impact on the environment is obtained, the environmental impact categories are obtained from the largest to the smallest, namely Land Use, Minerals, Resp. Inorganics, Acidification / Eutrophication, Climate change, Carcinogens, Ecotoxicity, Radiations, Resp. Organics, and the Ozone Layer. On the production knows, this category is caused by use are na an firewood taken from the garden / forest and pulp from the processing of soybeans. The smallest environmental impact is the Ozone layer, the damage to the ozone layer occurs due to the emission of gases containing chemicals. In the production of tofu, it only uses acetic acid which has little potential to damage the ozone layer.

At the single score stage, there is a grouping of environmental impact categories based on the types of losses incurred. These groups include human losses, ecosystem quality, and resources. In human health consists of impact categories carcinogens, respiratory organics, inorganics respiratory, climate change, radiation, and ozone layer. Then ecosystem quality consists of ecotoxicity, acidification / eutrophication, and land use. Meanwhile, the resources consist of minerals and fossil fuels. All potential environmental impacts based on the method of eco-indicator 99 is converted into a single score or value tu provision of furniture. The single score for each Damage Caegory is shown in Table 4.

Table 4. Results of Single Score Based on Damage Category

\begin{tabular}{|c|c|c|c|c|c|c|}
\hline Damage category & Unit & Total & Material & $\begin{array}{c}\text { Energi } \\
\text { Listrik }\end{array}$ & $\begin{array}{c}\text { Energi } \\
\text { biomassa }\end{array}$ & $\begin{array}{c}\text { Energi } \\
\text { Solar }\end{array}$ \\
\hline Total & $\mathrm{Pt}$ & 4076.345 & 1482.814 & 0.384622 & 2574.735 & 18.41152 \\
\hline Human Health & $\mathrm{Pt}$ & 1701.54 & 175.799 & 0.369793 & 1508.885 & 16.48605 \\
\hline Ecosystem Quality & $\mathrm{Pt}$ & 1409.057 & 878.1673 & 0.014828 & 529.7719 & 1.102646 \\
\hline Resources & $\mathrm{Pt}$ & 965.7484 & 428.8474 & 0 & 536.0781 & 0.822825 \\
\hline
\end{tabular}

Based on table 4, the single score results show the categories of environmental damage from the highest to the lowest, respectively Human Health, Ecosystem Quality, and Resources, which shows the biggest energy impact is also shown illustrated in Figure 5. 


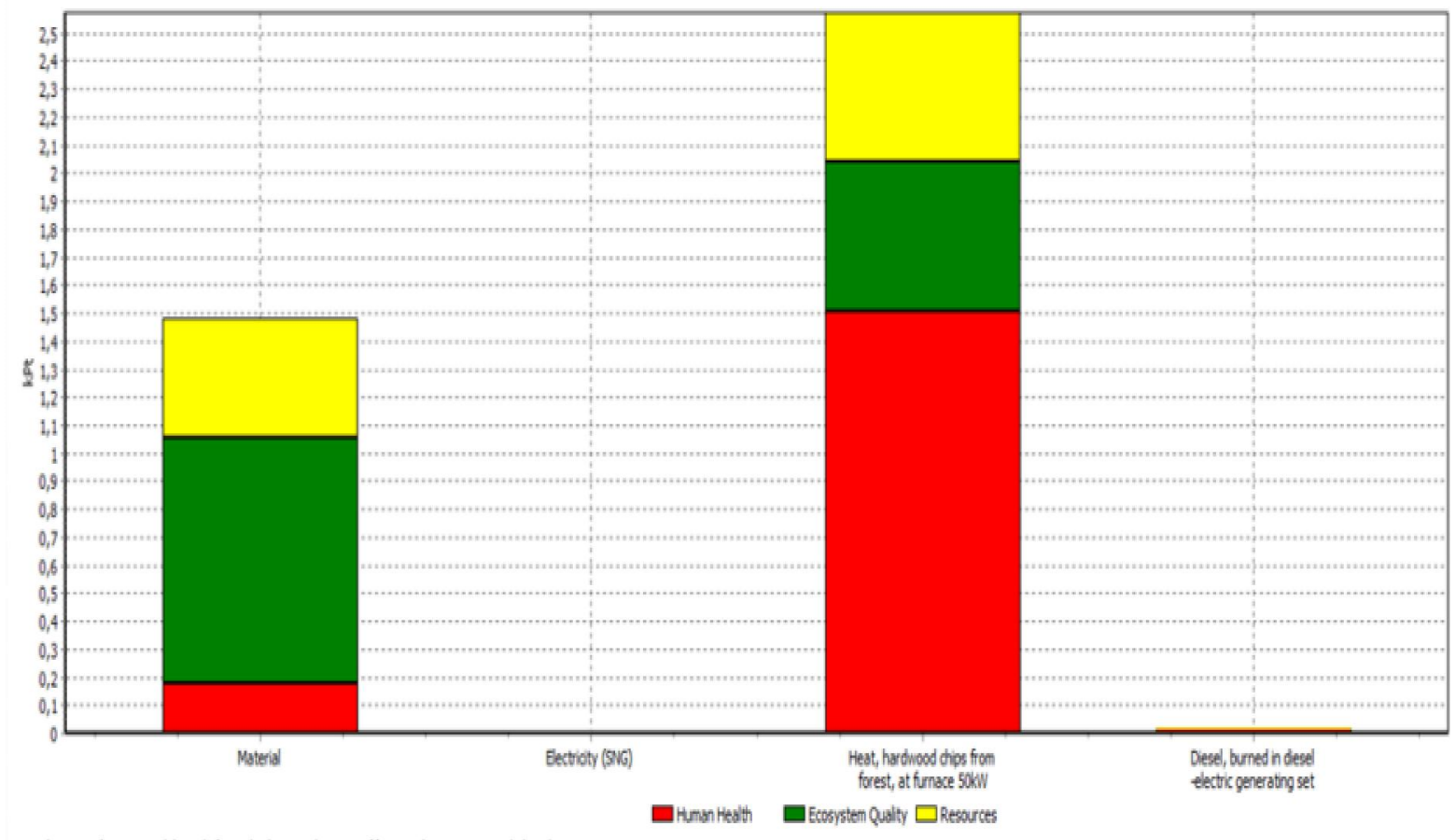

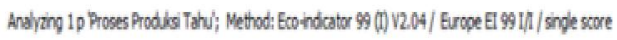

Fig. 5. Single Score Graph of Environmental Impact

Based on Figure 5 illustrates some of the factors that most contribute to the environmental impact of the tofu production process are:

1. The use of firewood as fuel in the soybean cooking process, where the amount of firewood used in June 2020 reached $60 \mathrm{~m}^{3}$ or $60,000 \mathrm{~kg}$ with a previously calculated energy period of 882,000 MegaJoules.

2. Production waste in the form of tofu dregs up to $190 \mathrm{~kg} /$ day and waste water from the production process.

Impact Assessment on the environmental category of environmental damage derived from the highest to lowest as follows:

a. Environmental Impact Analysis on Human Health

Based on the results of the Normalization value in the production process, it is known that the greatest impact is influenced by fuels in the form of diesel, electricity, and firewood. The main contribution dam pa $\mathrm{k}$ environment $\mathrm{h}$ uman health is the use of machine katel steam that generates a huge carbon dioxide from the burning of wood, especially in the respiratory tract.

b. Environmental Impact Analysis on Ecosystem Quality

Based on the results of the Normalization value in the production process, it is known that the impact of e cosystem quality is most affected by the use of chemicals and waste generated from the production process, namely the waste water from mixing water and vinegar which is flowed directly into the river which results in a deterioration of water quality plants in the surrounding environment.

c. Environmental Impact Analysis on Resources

Based on the results of the value of Normalization in the production process knows that impact most on the resources affected by the use of resources is done repeatedly, that the use of wood fuel that reaches 2 $\mathrm{m}^{3} / \mathrm{day}$, and does not guarantee environmental sustainability.

\section{ALTERNATIVE REPAIR}

Alternative improvements are made to reduce the impact of a production process on the surrounding environment. In the calculation of the single score is known to the highest environmental impact lies in Human Health (Human Health) caused by the use of firewood taken directly from the garden / forest and waste produ results $\mathrm{k}$ si. The use of firewood in the tofu production process in this study is not good because 
the impact on the surrounding environment is quite high and affects the impact of damage to the surrounding environment. An alternative improvement that can be done is to replace the fuel in the form of firewood to be replaced by biogas fuel.

Biogas is a solid, liquid or gas fuel produced from organic materials. Biogas can be produced directly from plants or indirectly from industrial, commercial, domestic, or agricultural waste. The choice of biogas as an alternative is because the tofu production process produces tofu dregs that reach $190 \mathrm{~kg} /$ day. The tofu waste can be used and processed into biogas. The scenario of using biogas in the tofu production process has been tested on SimaPro Software. The replacement of energy sources from firewood to biogas is carried out in the cooking process of soybeans. For many biogases is used, do the conversion equation of biogas with firewood, $1 \mathrm{~m}^{3}$ of biogas is equivalent to $3.5 \mathrm{~kg}$ Wood (Pamilia Coniwanti and Anthon, 2009).

It can be seen that the comparison of the use of biogas and wood against its environmental impacts is seen in Figure 6 and Table 5.

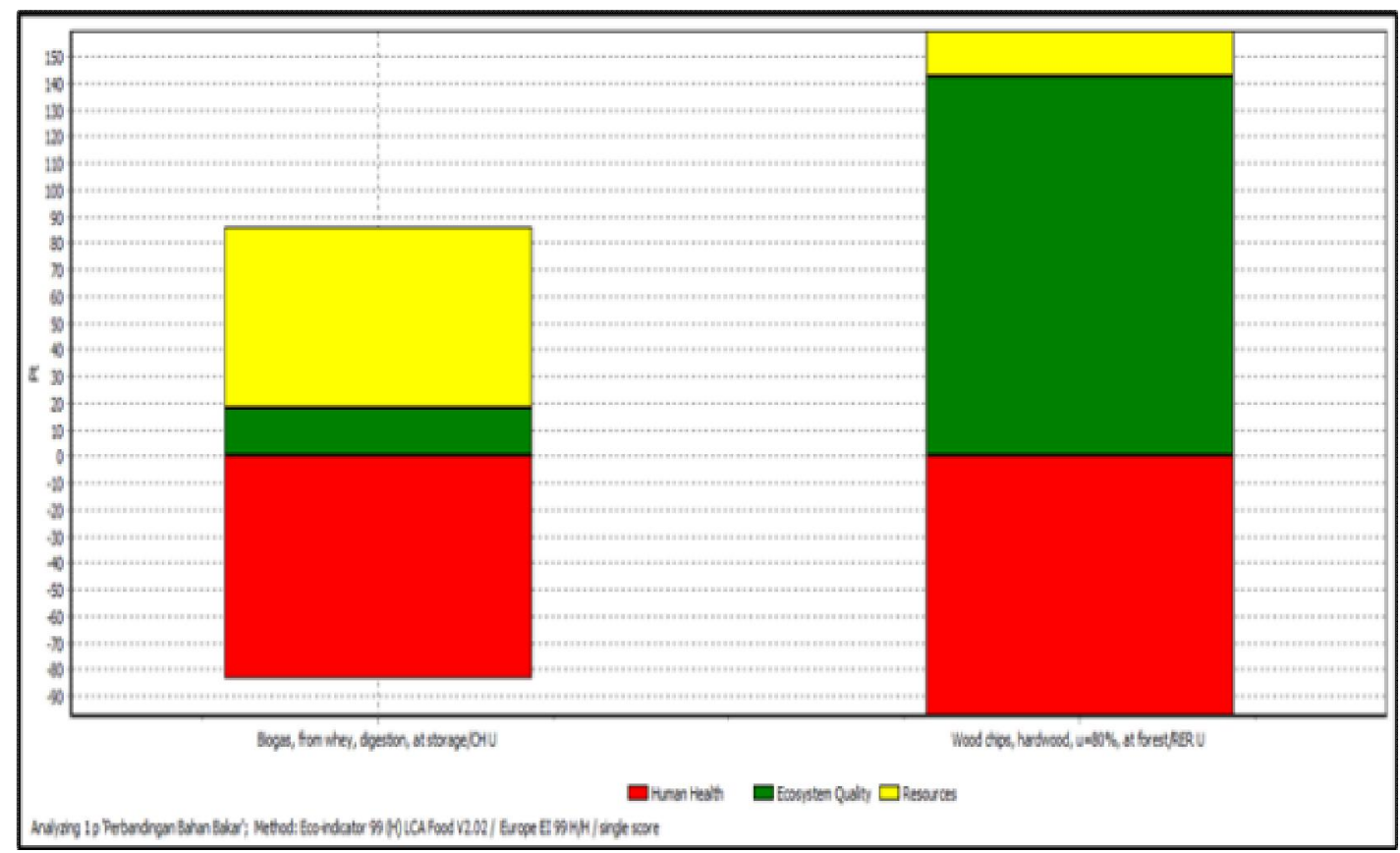

Fig. 6. Comparison Graph of Biogas and Firewood

Table 5. Single Score Comparison of Biogas and Firewood

\begin{tabular}{|c|c|c|c|c|}
\hline Damage category & Unit & Total & Biogas & Kayu Bakar \\
\hline Total & $\mathrm{Pt}$ & 172.1927 & 101.5039 & 70.68882 \\
\hline Human Health & $\mathrm{Pt}$ & -148.32 & -53.4752 & -94.8447 \\
\hline Ecosystem Quality & $\mathrm{Pt}$ & 181.1951 & 38.01397 & 143.1811 \\
\hline Resources & $\mathrm{Pt}$ & 139.3175 & 116.9652 & 22.35239 \\
\hline
\end{tabular}

Based on the single score, it is known the value of each damage category based on the use of biogas and firewood.

1. Human Health. In the Human Health categoryitem the use of biogas results in a low environmental impact with a value of -53.4752 compared to fuelwood with a value $-94,8447$.

2. Ecosystem Quality. In the Ecosystem Quality category, the use of biogas has a low environmental impact with a value of 38.013 compared to firewood with a value of 143.181 .

3. Resources. In the Resources category, the use of biogas produces environmental impacts with a value of 116.9652 while firewood with a value of 22.352 .

The advantages and disadvantages of using firewood are as follows:

1. Advantage

a. Saves production costs because firewood is taken directly from one's own garden / field. 
b. Food cooked using firewood has a more delicious taste than fuel.

2. Loss

a. If taken continuously without sustainability, it will cause natural disasters such as landslides, floods, and so on.

b. Air pollution is very high so that replacing the g gu gas exchange, plant growth, development of animals, and the human respiratory tract.

The use of biogas also has the following advantages and disadvantages:

1. Advantage

a. The community does not need to cut trees for firewood.

b. The cooking process is cleaner and healthier because it doesn't emit smoke.

c. Can reduce greenhouse gas emissions by reducing the use of wood fuel.

d. Being one of the alternative processing a waste, because reusing the results of the production process.

2. Loss

a. Requires more funds for applications in the form of a biogas installation.

b. Not very well known to the public

Based on the above comparison, it is known that the use of biogas can reduce the environmental impact that was previously caused by the use of firewood.

\section{CONCLUSION}

Based on the results of data processing and analysis, the following conclusions can be drawn.

1. Based on the results of the processing of the Life Cycle Assessment on the production process out using the software SimaPro 7, earned value single score of $4076.345 \mathrm{Pt}$, with the environmental impact Human Health at 1701.54 (41.7\%), Ecosystem Quality of 1409.057 (34, 6\%), and Resources 965.7484 (23.7\%).

2. Several factors that have an impact on the environment include the use of wood fuel in the soybean cooking process and the waste from the tofu production process.

3. Based on the environmental impact, recommendations for improvement are obtained by replacing wood fuel with biogas fuel which has a low environmental impact because it is made from tofu pulp itself.

\section{REFERENCES}

[1] S. Djayanti, "Study on the Application of Clean Production in the Tofu Industry in Jimbaran Village, Bandungan, Central Java," J. Ris. Technol. Deterrent. Pollution Ind. , vol. 6, no. 2, pp. 75-80, 2015.

[2] Government of the Republic of Indonesia, "Law Number 23 Year 1997 concerning Environmental Management," State Gazette of the Republic of Indonesia. 1997 , no. 1, p. 21, 1997.

[3] F. Saputra, S. Sutaryo, and A. Purnomoadi, "Utilization of Solid Waste in Tofu Industry as Co-Substrate for Biogas Production Utilization of Tofu Cake as Co-Substrate in Biogas Production," J. Apl. Technol. Food, vol. 7, no. 3, pp. 117-121, 2018.

[4] S. Saenab, M. Henie, I. Al, F. Rohman, and AN Arifin, "Utilization of Tofu Industry Liquid Waste as Liquid Organic Fertilizer (POC) to Support Makassar City's Lorong Garden (Loose) Program," Pros. Semin. Nas. Indonesian Megabiodiversity., no. April, pp. 31-38, 2018.

[5] M. Rosyidah, "Analysis of Musi River Water Pollution Due to Industrial Activities, " vol. 3, pp. 21-32, 2018.

[6] "Application of Life Cycle Assessment to Measure Greenhouse Gas Emissions from Tofu Production Activities," pp. 475-480, 2017.

[7] DY Irawati and D. Andrian, "Environmental Impact Analysis on Drinking Water Treatment Plants (IPAM) Using the Life Cycle Assessment (LCA) Method," J. Tek. Ind. , vol. 19, no. 2, p. 166, 2018.

[8] IP Bogor, "LCA (Life Cycle Assassment) On Paper Production From Tebu Ampas Paper Review Journal Rozana," 2013.

[9] TR Harjanto, M. Fahrurrozi, and IM Bendiyasa, "Life Cycle Assessment of PT Holcim Indonesia Tbk Cement Factory. Cilacap Plant: Comparison between Coal Fuel and Biomass, ”vol. 6, no. 2, pp. 51-58, 2012.

[10] masrizal Khaidir, "R Mixed Method Research Masrizal *," J. Kkes. Masy. , vol. 6, pp. 53-56, 2011. 